\title{
Estimation of Electric Energy Required by Electric Vehicles based on Travelled Distances in a Residential Zone
}

\section{Estimación de la Energía Eléctrica Requerida por los Vehículos Eléctricos en Función de las Distancias Recorridas en una Zona Residencial}

\author{
Cristian C. Mendoza ${ }^{1 *}$, Adriana M. Quintero ${ }^{1}$, Francisco Santamaria ${ }^{1}$, \\ Jorge A. Alarcón ${ }^{1}$ \\ ${ }^{1}$ Universidad Distrital Francisco José de Caldas, Bogotá, Colombia
}

\begin{abstract}
This paper presents a methodology to estimate electric energy required by electric vehicles, taking into account driving habits and mobility statistics of private vehicles. Initially, a probability function of accumulated distances that an electric vehicle travels on a normal operation day is developed based on mobility patterns (travelled distances, number of trips, etc.). The obtained information is used to generate probability distributions for travelled distances by vehicles and for energy required by a vehicle after its daily operation. Probability distributions allow assigning to each vehicle a travelled distance and a required energy with a behavior based on real data. From obtained functions, energy required by each electric vehicle is analyzed, which is essential information to evaluate the effect of massive connection to the power grid. In this way, under the proposed methodology it is provided a tool that could predict the amount of energy required by a given quantity of electric vehicles that are connected to the grid. Finally, the proposed methodology was validated in Bogota, Colombia determining the probability distribution of the energy consumed per vehicle.
\end{abstract}

Keywords: Probability Distribution, Travelled Distance, Energy Consumption, Electric Vehicles, Batteries.

\section{Resumen}

Este artículo plantea una metodología para estimar la energía eléctrica requerida por los vehículos eléctricos, teniendo en cuenta los hábitos de conducción y estadísticas de movilidad de los vehículos particulares. Inicialmente se construye la función de probabilidad de las distancias acumuladas que recorre el vehículo eléctrico en un día de operación normal a partir de los patrones de movilidad (distancias recorridas, número de desplazamientos, etc.). Con la información obtenida se generan distribuciones de probabilidad para las distancias recorridas por los vehículos y para la energía requerida por un vehículo luego de un día de recorrido normal. Las distribuciones de probabilidad permiten asignar a cada vehículo, una distancia recorrida y una energía requerida siguiendo un comportamiento basado en datos reales. Con las funciones obtenidas se determina la energía requerida por un vehículo, que es una información indispensable para evaluar el efecto de la conexión masiva de estos en la red eléctrica. De esta manera, bajo la metodología propuesta se provee una herramienta que permite predecir la cantidad de energía requerida por un determinado número de vehículos eléctricos que se conectan a la red. Finalmente, la metodología propuesta se valida en Bogotá, Colombia determinando la distribución de probabilidad que representa la energía consumida por vehículo.

Palabras clave: Distribución de Probabilidad, Distancia Recorrida, Consumo de Energía, Vehículos Eléctricos, Baterías.

*Corresponding Author.

E-mail: ccmendozag@correo.udistrital.edu.co
How to cite: Mendoza, C. C., Quintero, A. M., Santamaria, F., Alarcón, J. A., Estimation of electric energy required by electric vehicles based on travelled distances in a residential zone, TECCIENCIA, Vol. 12 No. 21., 17-24, 2016, DOI: http:/dx.doi.org/ 


\section{TECCIENCIA}

\section{Introduction}

The steady increment in electricity demand and accelerated reduction of fossil resources have resulted in the search for new energy sources, as well as the study of more efficient and environmentally friendly technologies; the transportation is a sector of great interest at this moment [1] [2] [3]. For this reason, the automotive industry and several governments have understood the electric vehicle as a technology that provides a more efficient transportation along with a gradual reduction of greenhouse gas emissions [4] and as a solution against the consumption of oil-based fuels [5] [6] [7]. Nonetheless, it is so important to assess the impact that the massive use of these vehicles could produce in the low and medium voltage grid.

Previous studies regarding the massive connection of electric vehicles indicate it may have a significant impact on the grid, since under a massive penetration scenario, electric power demand would increase, affecting the system capacity, power quality and system reliability [8] [9] [10] [11] [12]. Additionally, it is possible that the power grid infrastructure requires extensions or reconfigurations [13], and needs to implement a management system to regulate the charging of the electric vehicles integrated into the network.

Therefore, it is necessary to estimate the energy consumed by an electric vehicle when it makes a particular travel, since this provides information about required power and energy to charge its battery.

Some researches indicate that the required energy to make a trip depends on the driving cycles or utilization curves [14] [15]. These measurements allow determining the consumption of the electric vehicle in terms of its efficiency in order to make comparisons between different models [16]. However, estimating the energy consumed by a group of vehicles with different features makes more complex this approach, considering that some of the input variables such as travelled distance and braking and acceleration intervals are unknown.

Therefore, this paper presents a methodology for calculating the energy required by an electric vehicle based on a probabilistic model, which considers the behavior of mobility patterns of particular vehicles in the zone under study and the specific characteristics of electric vehicles available in the market. Finally, this methodology is experimentally validated in Bogotá, Colombia. For achieving this, we take into account the mobility patterns of internal combustion vehicles, since there are not data about electric vehicles mobility in the city.

During the third stage physical adsorption occurs of the reactive silanols through the hydroxyl groups of fiber via the formation of hydrogen bonds. The final stage consists of the actual formation of the silanol graft with the natural fiber, once the solvent had been eliminated and with increased temperature the formation of the $-\mathrm{Si}-\mathrm{O}-\mathrm{C}$ - bond takes place with release of water [17] [18].

\section{Methods and materials}

The energy consumption of electric vehicles is a function of several variables and therefore, it is important to present a methodology to estimate the aggregate demand, which represents an additional load for the power grid. In [19] the charge of electric vehicles is modelled using the penetration level of electric vehicles, traffic patterns and different charge scenarios. Additionally, in that study driving patterns are used only to determine the moment in which vehicles are charged assuming the same average travelled distance. Therefore, the required energy is calculated as the efficiency of the vehicle multiplied by the average travelled distance in all cases; however, distances and energy requirements are different for each type of vehicle and for each user according to particular needs or usage habits.

Furthermore, Shaaban and El-Saadany [20] propose a model to define the annual energy consumed by a group of PHEVs (Plug-in Hybrid Electric Vehicle) from historical data. Obtained results show that the highest consumption of 100 PHEVs occurs at 17:00 hours and it is close to $200 \mathrm{~kW}$; however, a probability function of the energy consumed by a vehicle is not presented. On the other hand, $\mathrm{Yi}$ and $\mathrm{Li}$ in [21] determine the probability function of the average travelled distance per day to establish the level of the battery charge, in order to define the energy requirement of the electric vehicle. Additionally, in that study the calculated energy considers a linear charge characteristic for the battery. However, this assumption does not correspond with the actual behavior of the battery for recharging.

\section{Energy consumption estimation}

This paper proposes a methodology based on mobility patterns of the city and a specific zone selected for characterizing the behavior of electric vehicles, as well as the information corresponding to specific consumption for batteries of the most representative vehicles in the market. This information is essential to establish a differentiated 


\section{TECCIENCIA}

consumption of vehicles considering the battery capacity that varies according to its type, technology and autonomy, which modifies the charge curve followed by each vehicle during reloading.

In order to achieve this, the number of trips made by each user and the travelled distance in each trip were evaluated to estimate the total travelled distance at the end of the day. Based on these data, it was possible to obtain a probability function representing the probable distances travelled by users, which allows assigning a travelled distance to each vehicle taking into account the frequency of occurrence of each event (to travel a given distance).

Once the probability function of the accumulated travelled distances was established, it was assumed that the energy efficiency of the batteries was the same in all cases and the energy required by the electric vehicle to recharge the battery after a normal day of operation was afterward calculated.

Finally, the allocation of travelled distances in a random way to each of the users connected to the power grid enabled the calculation of the energy used by each vehicle during the day. As a methodology based on a probabilistic model, each time an electric vehicle was connected to the system, it had a different state of charge, which was similar to the actual behavior of the battery. Knowing this, it would be possible to calculate the total energy required to simultaneously charge several vehicles.

The detailed procedure under which this methodology was developed is shown in the flowchart of Figure 1. The four major steps are described in the paragraphs below.

1. First, the population of the zone selected must be identified. Then, the necessary information to know the driving habits of the owners of private vehicles must be collected taking into account aspects such as travelled distances, socioeconomic status, number of daily trips and the reason why the trip was made, data available from mobility studies or statistics developed for the city. If that information is not available, the first step is to select the study zone and population, and then obtain relevant data through studies and surveys.

2. Once the information is obtained, it must be constructed a probability function of the daily travelled distances by vehicles when considering a single trip. However, the needs of users are different, and they could require more than one trip, so the accumulated trips that the vehicle can make per day must be considered, as shown in Figure 2.

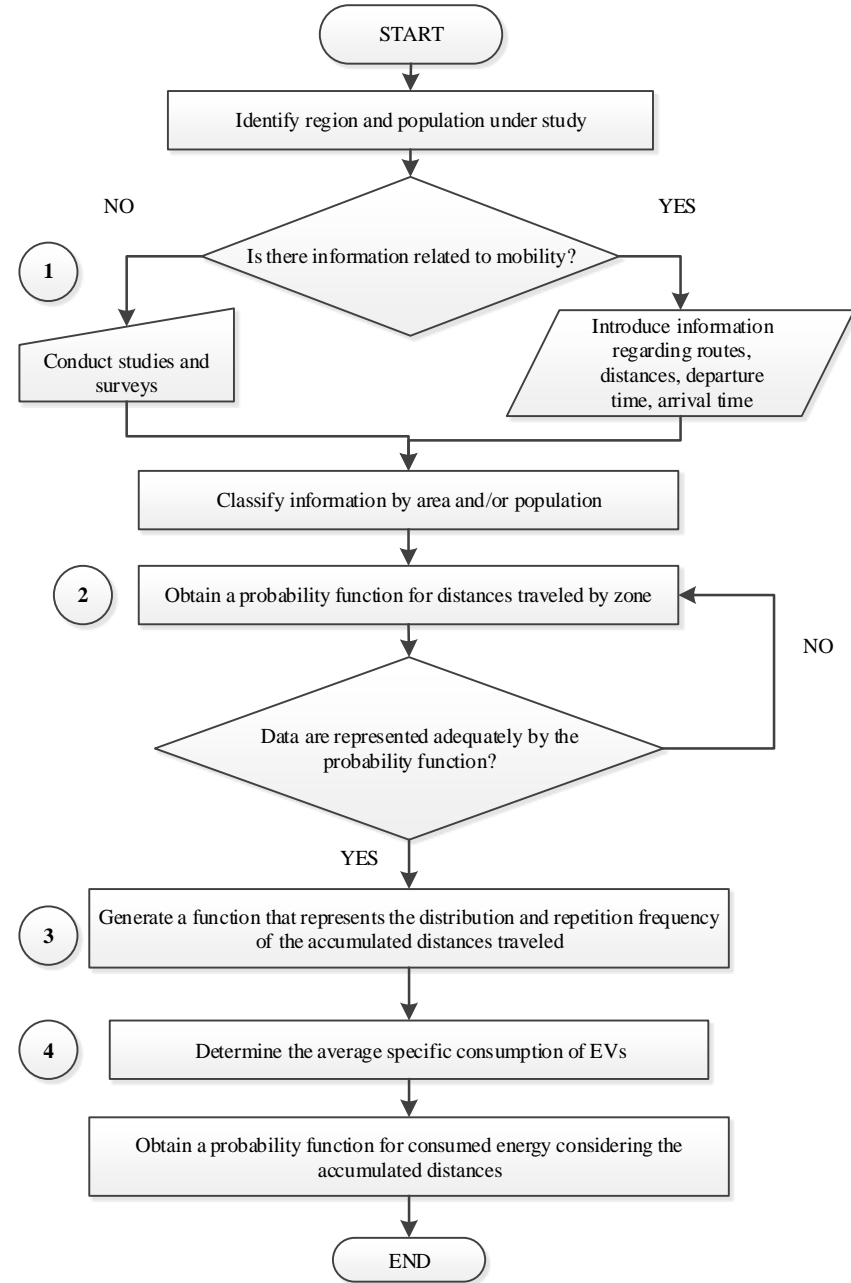

Figure 1 Flowchart of proposed methodology. Source: Own authorship.

To calculate the total distance travelled by each vehicle, it must be determined the number of users (\# Vehicles sl $_{\text {) }}$ ) that travel a specific distance according to its socioeconomic level $(s l)$. To find the number of users or vehicles, the data from city's mobility surveys that corresponds to the amount of people according to socioeconomic level (Persons $s$ ) and the percentage of private vehicles that have these persons $\left(\%\right.$ Vehicles $\left._{s l}\right)$ must be employed, as presented in (1).

$\#$ Vehicles $_{s l}=$ Persons $_{s l} *\left(\%\right.$ Vehicles $\left._{s l}\right)$

In this way, a relationship between the daily distances covered by electric vehicles and the amount of accumulated trips was obtained. From these samples, it was constructed the probability function of the daily travelled distances depending on the frequency of 


\section{TECCIENCLA}

occurrence, taking into account that the discharge of batteries depends on this variable.

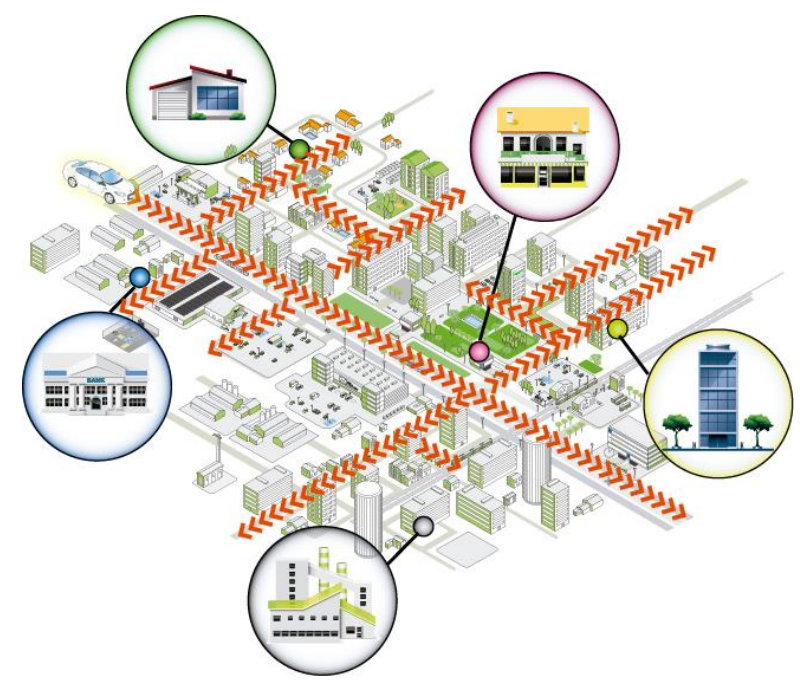

Figure 2 Representation of accumulated trips to different destinations that an electric vehicle could make in a day. Source: Author.

3. Step 3 consists on randomly assign each vehicle a distance and determine the average specific consumption of batteries, calculated from the characteristics of the most representative electric vehicles in the market.

4. Finally, with the accumulative travelled distances $\left(D_{\text {travelled }}\right)$ and the average specific consumption of batteries $\left(\mathrm{C}_{b a t}\right)$, obtained in steps 2 and 3 , it was constructed the probability function of the energy required by each electric vehicle ( $\left.E_{\text {consumed }}\right)$, which was calculated as presented in (2).

$E_{\text {consumed }}[k W h]=D_{\text {travelled }}[k m] * \mathrm{C}_{\text {bat }}\left[\frac{\mathrm{kWh}}{\mathrm{km}}\right]$

Knowing the energy consumed by each vehicle through the proposed methodology, it was possible to calculate the total energy that the power grid must be able to supply to recharge the batteries of the plugged vehicles.

\section{Results and discussions}

Mobility conditions includes factors that affect the vehicle consumption such as: the number of trips made each day, the travelled distance in each trip, and the number of arrivals to home every hour in a day. Once this information is available, it is possible to determine the accumulated distances from probability functions, which allow establishing the travelled distance by a vehicle in one day, as shown in Figure 1. Based on this probability function of accumulated distances, it is possible to calculate the consumed energy during the trips to finally represent consumption or expected discharge of battery. In order to present the obtained results of applying the proposed methodology, a case study based on mobility data of the city of Bogotá, Colombia was considered.

\subsection{Daily distances travelled by private vehicles}

Considering that the distance travelled by a vehicle in a day depends on the habits, needs and location of its owner, the developed model takes into account that the trips in Bogotá are mainly for working [22]. This involves knowing both the travelled distances to main zones of the city as well as the number of private vehicles travelling these distances.

Table 1 Number of trips and travelled distances by zone in Bogotá. Source: [22]

\begin{tabular}{|c|c|c|}
\hline Zone & $\begin{array}{c}\text { Distances } \\
{[\mathrm{km}]}\end{array}$ & $\begin{array}{c}\text { Number of travels } \\
\text { by zone in private } \\
\text { vehicle }\end{array}$ \\
\hline Américas & 8.94 & 375.00 \\
Bosa & 14.07 & 250.00 \\
Calle 72 - Calle 100 & 6.83 & 333.33 \\
Centro histórico & 6.32 & 333.33 \\
internacional & 5.60 & 333.33 \\
Chapinero & 9.64 & 333.33 \\
Corabastos & 14.75 & 141.67 \\
Danubio - Río Tunjuelito & 11.68 & 250.00 \\
Delicias- Ensueño & 19.51 & 133.33 \\
Eje de Integración de los & 7.67 & 283.33 \\
Llanos & 10.05 & 291.67 \\
Ferias & 9.16 & 500.00 \\
Fontibón - Aeropuerto & 10.25 & 291.67 \\
Prado - Veraniego & 7.09 & 183.33 \\
Quirigua - Bolivia & 7.34 & 366.67 \\
Restrepo - Santander & 7.48 & 283.33 \\
Salitre - Zona Industrial & 11.43 & 333.33 \\
Siete de agosto & 12.71 & 291.67 \\
Suba & 6.95 & 483.33 \\
Toberín - La paz & 9.49 & 208.33 \\
Usaquén - Santa Bárbara & & 6000.00 \\
Veinte de julio & & \\
Total & & \\
\hline & & \\
\hline
\end{tabular}

In order to know the distances travelled by private vehicles, it is applied the Formulation of the Mobility Master Plan for Bogotá [23], a document used for the analysis of trip behavior, which includes the travelled distances to main zones of the city for working, as shown in Table 1. However, 


\section{TECCIENCIA}

the number of vehicles travelling these distances is not presented in this study, so it must be obtained from the Mobility Survey for Bogotá [22] with the number of daily trips taking place in the city for this reason. The information presented in [22] is defined according to the income level of the population that owns and uses a vehicle.

Once the number of vehicles and the distances they travel in each zone are obtained, data are grouped according to the frequency of the events, i.e. the times that each travelled distance repeats, thus obtaining a logarithmic normal probability function with $\mu=2.185$ and $\sigma=0.277$, as shown in Figure 3. For example, from Table 1 and Figure 3 it is probable to find 375 trips per day in private vehicle travelling $8.94 \mathrm{~km}$ on the Americas zone, i.e., this frequency corresponds to the number of vehicles going across the zone.

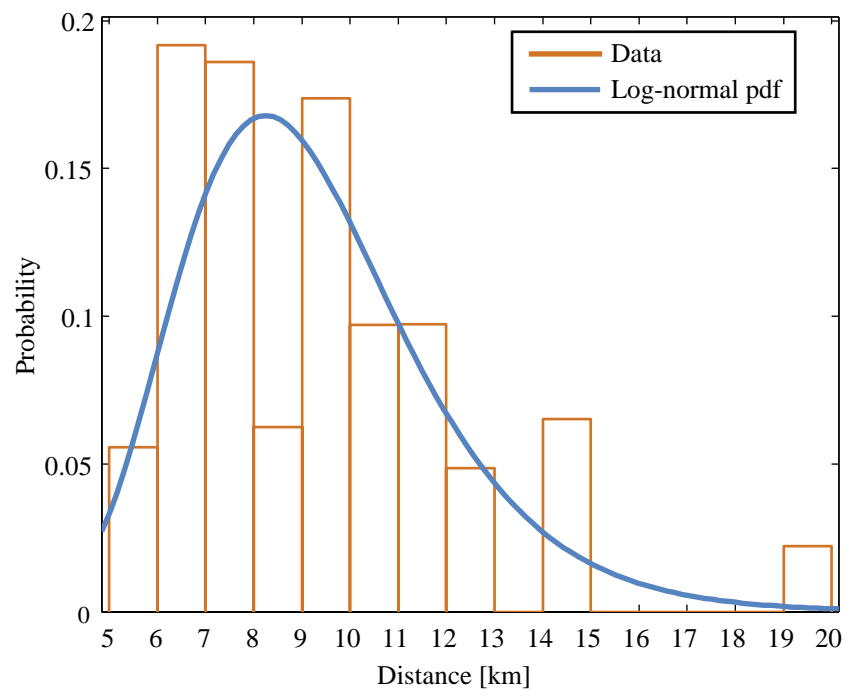

Figure 3 Probability function of the distances travelled per day by private vehicles in Bogota considering a single travel to different zones. Source: Own authorship.

\subsection{Probability function of accumulated travelled distances}

Since vehicles can make various trips per day and travel to different places, predicting this behavior for each vehicle would require a much more complex model. However, considering that a number of vehicles travel a quantity of trips in common, the model only need to know the behavior for a particular group.

Following this approach, the percentage of private vehicles that make certain number of trips per day must be found from the number of trips that someone makes every day according to the socioeconomic level to which the person belongs. The number of people and percentage of private vehicles per socioeconomic level are data provided by the socioeconomic characterization in Bogota [22]. By including this information in (1) an approximate number of vehicles making a number of trips per socioeconomic level can be found, as shown in the last column of Table 2 .

Table 2 Number of vehicles and average trips by person in Bogotá according to socioeconomic level.

\begin{tabular}{|c|c|c|c|c|}
\hline $\boldsymbol{s l}$ & $\begin{array}{c}\text { People per } \\
\boldsymbol{s} \boldsymbol{l}\end{array}$ & $\begin{array}{c}\% \text { of } \\
\text { vehicle } \\
\text { s per } \boldsymbol{s} \boldsymbol{l}\end{array}$ & $\begin{array}{c}\text { Number of } \\
\text { vehicles per } \boldsymbol{s} \boldsymbol{l}\end{array}$ & $\begin{array}{c}\text { Trips/ } \\
\text { Person } \\
*\end{array}$ \\
\hline 1 & 705,536 & $1.18 \%$ & $8,325.32$ & 2.03 \\
\hline 2 & $2^{\prime} 938,962$ & $9.00 \%$ & $264,506.58$ & 2.2 \\
\hline 3 & $2^{\prime} 668,455$ & $19.00 \%$ & $507,006.45$ & 2.25 \\
\hline 4 & 706,191 & $37.00 \%$ & $261,290.67$ & 2.49 \\
\hline 5 & 195,873 & $53.00 \%$ & $103,812.69$ & 2.62 \\
\hline 6 & 130,261 & $66.00 \%$ & $85,972.26$ & 2.65 \\
\hline $\begin{array}{c}\text { Tota } \\
1\end{array}$ & $7{ }^{\prime} 345,278$ & & $1230,913.97$ & \\
\hline
\end{tabular}

Following the indicated procedure it was found that the total number of calculated vehicles is close to $1 ' 284.304$, which represents the real value of private vehicles in Bogotá [22]. Once the number of vehicles per socioeconomic level is discriminated, it is possible to establish a relationship between the percentage of vehicles and trips a person makes in a day, as shown in Figure 4, where each bar represents a socioeconomic level (between 1 and 6). For example, it is expected that about 8325 vehicles make 2.03 trips in a day in socioeconomic level 1.

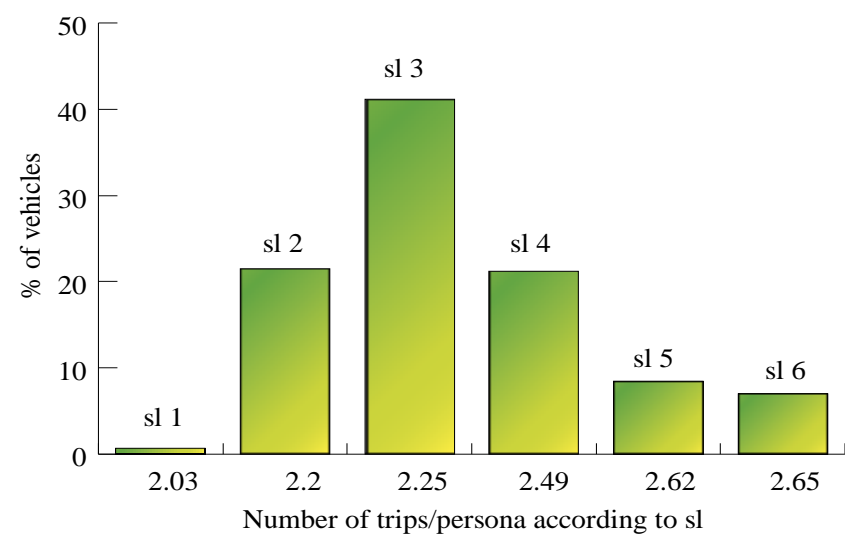

Figure 4 Percentage distribution of vehicles according to socioeconomic level and the number of trips made daily in Bogotá. Source: Own authorship.

In this way the vehicles are grouped according to the number of trips, considering that people making the trips drive private vehicles. In Figure 4, it is also possible to note that the majority of vehicles make between 2.2 and 2.62 trips per day. Additionally, considering that the sample of travelled distances in Figure 3 presents the data for a trip, then it is 


\section{TECCIENCIA}

possible to generate a quantity of distances proportional to the number of trips. For example, from $100 \%$ private vehicles travelling in the city, $0.68 \%$ makes 2.03 trips. Hence, $0.68 \%$ of the travelled distances is multiplied by 2.03 .

Therefore, generating a sample of 1000 distances which follow the probability distribution of Figure 3 and taking into account the percentages obtained in Figure 4, the number of vehicles that make a number of trips in the city is found. Thus, a relationship between the number of vehicles and the number of trips according to socioeconomic level, can be established, as shown in Figure 5 in accordance with Table 3 .
Table 3 Number of samples of the distances travelled by vehicles and their trips.

\begin{tabular}{|c|c|c|c|c|}
\hline $\begin{array}{c}\text { Generated } \\
\text { distances }\end{array}$ & $\boldsymbol{s} \boldsymbol{l}$ & $\begin{array}{c}\text { \% of the total } \\
\text { of vehicles by } \\
\text { sl }\end{array}$ & $\begin{array}{c}\text { Number } \\
\text { of } \\
\text { samples }\end{array}$ & $\begin{array}{c}\text { Trip } \\
\text { s }\end{array}$ \\
\hline \multirow{3}{*}{1000} & 1 & $0.68 \%$ & 6.8 & 2.03 \\
\cline { 2 - 5 } & 2 & $21.49 \%$ & 214.9 & 2.2 \\
\cline { 2 - 5 } & 3 & $41.19 \%$ & 411.9 & 2.25 \\
\cline { 2 - 5 } & 4 & $21.23 \%$ & 212.3 & 2.49 \\
\cline { 2 - 5 } & 5 & $8.43 \%$ & 84.3 & 2.62 \\
\cline { 2 - 5 } & 6 & $6.98 \%$ & 69.8 & 2.65 \\
\hline Total & & $100.00 \%$ & 1000 & \\
\hline
\end{tabular}
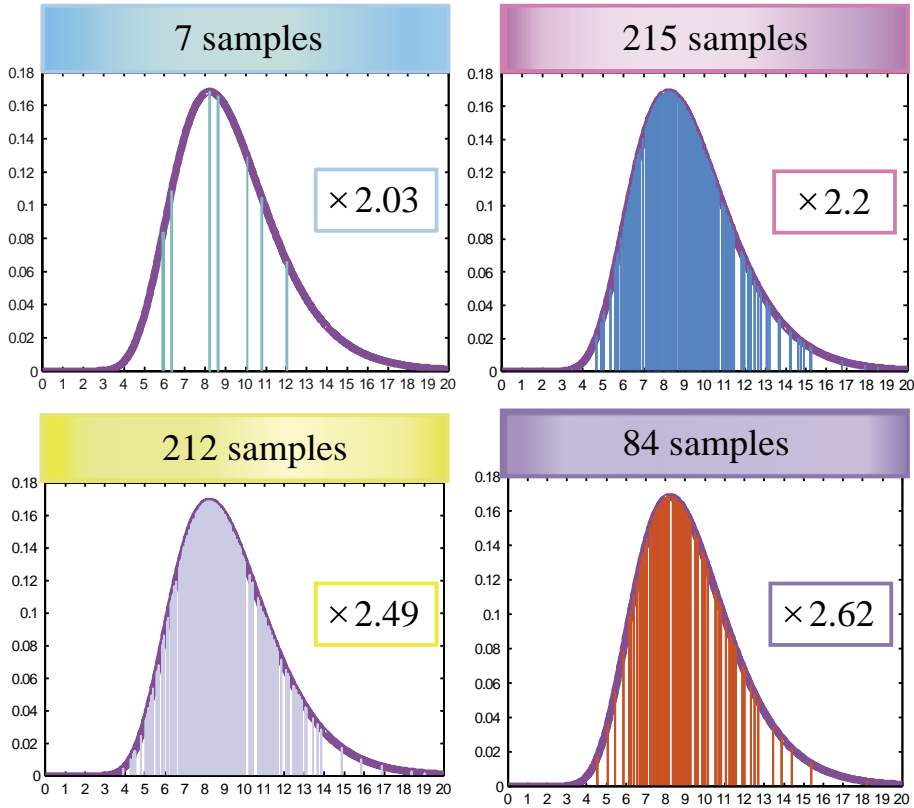

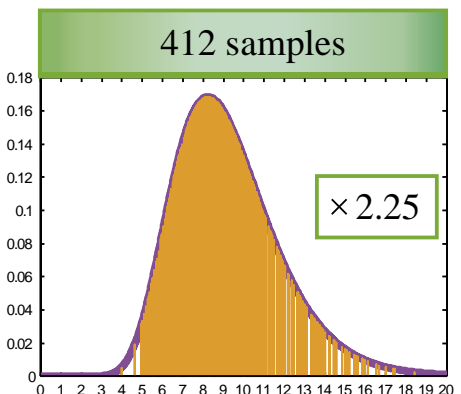

70 samples

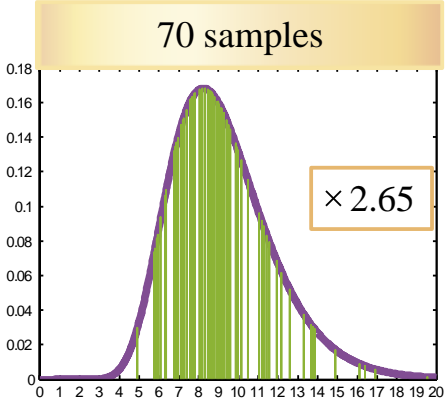

Figure 5 Sampling of the distances travelled by electric vehicles according to the classification into groups by the number of trips made during the day according to the socioeconomic level. Source: Own authorship.

Finally, analyzing the behavior of the generated distances for each group of samples (associated with a socioeconomic level), a logarithmic normal probability distribution was found with $\mu=3.744$ and $\sigma=0.396$ displaced to the right, since the accumulated trips the vehicle travels per day in the city are included, as shown in Figure 6.

\subsection{Probability function of energy consumed by electric} vehicles

From the probability function of the accumulated distances travelled by vehicles (Figure 6), it is possible to determine the energy consumption of electric vehicles in the city. However, the consumption of the battery of an electric vehicle varies from one model to another as shown in Table 4 [24].

Defining a specific consumption for each type of battery would extend too much the model; for this reason, during the development of the research, a specific consumption in the battery close to $0.158 \mathrm{kWh} / \mathrm{km}$ [24] was adopted, which corresponds to the average value of energy consumptions of most representative market electric vehicles. Thus, the energy consumed by an electric vehicle is calculated according to (2). With the expected probability function for travelled distances in the city and the specific consumption of electric vehicles, it is possible to obtain the probability distribution for the energy consumed by the electric vehicle, as shown in Figure 7. 


\section{TECCIENCIA}

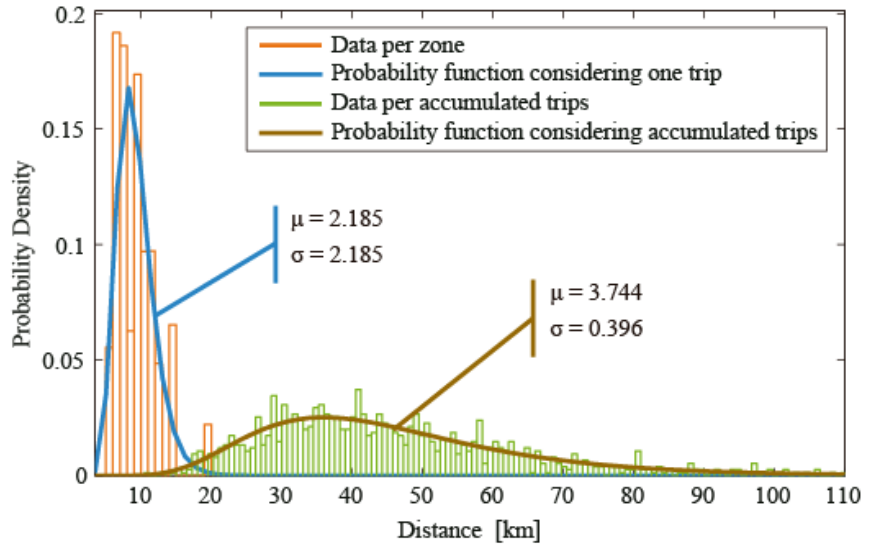

Figure 6 Probability distribution of travelled distance when considering accumulated trips. Source: Own authorship.

Table 4 Features of expected capacity and consumption of different types of electric vehicles available in the market.

\begin{tabular}{|c|c|c|}
\hline $\begin{array}{c}\text { Brand of the } \\
\text { Electric Vehicle }\end{array}$ & $\begin{array}{c}\text { Capacity } \\
{[\mathbf{k W h}]}\end{array}$ & $\begin{array}{c}\text { Consumption } \\
{[\mathbf{k W h} / \mathbf{k m}]}\end{array}$ \\
\hline BYD F3DM & 16.5 & 0.160 \\
\hline BYD e6 (200 kW) & 59.4 & 0.175 \\
\hline BYD e6 (75 kW) & 59.4 & 0.160 \\
\hline Mini-E & 35.0 & 0.130 \\
\hline Mitsubishi iMiEV & 16.5 & 0.100 \\
\hline Nissan Leaf & 24.0 & - \\
\hline Tesla Roadster & 51.5 & 0.231 \\
\hline $\begin{array}{c}\text { Toyota Prius Plug- } \\
\text { In Hybrid }\end{array}$ & 5.0 & 0.062 \\
\hline \multicolumn{2}{|c}{} \\
\hline
\end{tabular}

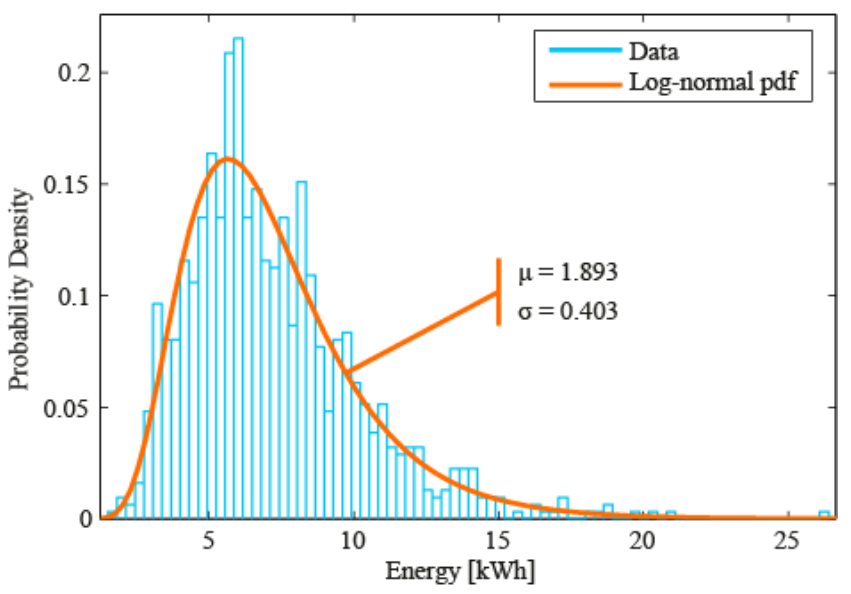

Figure 7 Probability function of the energy consumed by the electric vehicle. Source: Own authorship.
In this way, the probability function of the energy required by each electric vehicle that connects to the system is obtained, which will allow the power distribution company to determine if the system is able to supply the $\mathrm{kWh}$ corresponding to the energy requirement by these vehicles.

Taking into account that the proposed methodology is based on real data and probability functions, its implementation will allow establishing the actual behavior of vehicle batteries, thus obtaining the energy required by the system to recharge and the impact the simultaneous connection of vehicles will produce on the system capacity [25] [26]. This represents an advantage for both the power grid operator, who will be able to make the necessary adjustments on the infrastructure, and the user, who will not evidence problems on the energy service delivery.

\section{Conclusions}

The energy required by the electric vehicle depends on mobility conditions corresponding to the study zone, i.e., trips to home, travelled distances by zone and number of trips, as well as the own characteristics of batteries. Although the presented results are based on the mobility behavior of the city of Bogotá, the proposed methodology for estimating the power demand of electric vehicles can be implemented according to the mobility patterns of any city or study zone.

Knowing the energy requirement of each of the vehicles that will be connected to the distribution system, the power grid operator will be able to evaluate the infrastructure expansion or to establish a strategy to avoid quality and energy service delivery problems.

Finally, the proposed probabilistic model allows estimating the energy required for each electric vehicle, ensuring that each vehicle will have a different charging condition. This model can be extended in future studies including aspects such as: geographical conditions, temperature, usage habits, weather conditions, among others.

\section{References}

[1] International Energy Agency, «2014 Anual Report,» IEA, París, 2014.

[2] International Energy Agency, «Energy Technology Perspectives 2015,» IEA, París, 2015.

[3] Muñoz, Y. et al «Evaluation of a hybrid system of renewable electricity generation for a remote area of Colombia using HOMER software,» TECCIENCIA, vol. 9, nº 17, pp. 45-54, 2014.

[4] J. D. Bishop, N. P. Martin \& A. M. Boies, «Cost-effectiveness of alternative powertrains for reduced energy use and $\mathrm{CO} 2$ emissions in passenger vehicles,» Applied Energy, vol. 124, pp. 44-61, 2014. 


\section{TECCIENCIA}

[5] L. C. Triola, «Energy \& National Security: An Exploration of Threats, Solutions, and Alternative Futures,» de Conference Energy 2030, Atlanta, Georgia, USA, 2008.

[6] L. A. P. Peres, J. F. M. Pessanha, J. V. Serra, F. M. F. Particelli \& A. C. I. Caldas, «Analysis of the Use of Electric Vehicles by Electric Utility Companies Fleet in Brazil,» IEEE Latin America Transactions, vol. 9, $\mathrm{n}^{\circ}$ 7, pp. 1032-1039, 2011.

[7] «Green Transportation in India: Need Analysis and Solution,» de International Conference on Control, Automation, Robotics and Embedded Systems (CARE) , Jabalpur, India, 2013.

[8] G. A. Putrus, P. Suwanapingkarl, D. Johnston, E. C. Bentley \& M. Narayana, «Impact of Electric Vehicles on Power Distribution Networks,» de Vehicle Power and Propulsion Conference, Michigan, 2009.

[9] S. Shao, M. Pipattanasomporn \& S. Rahman, «Grid Integration of Electric Vehicles and Demand Response with Customer Choice,» IEEE Transaction on Smart Grid, vol. 3, n 1, pp. 543-550, 2012.

[10] L. Pieltain, T. Gómez, R. Cossent, C. Domingo \& P. Frías, «Assessment of the Impact of Plug-in Electric Vehicles on Distribution Networks,» IEEE Transactions on Power Systems, vol. 26, n 1 , February 2011.

[11] C. Farkas, K. I. Szabó \& L. Prikler, «Impact Assessment of Electric Vehicle Charging on a LV Distribution System,» de 3rd International Youth Conference on Energetics (IYCE), Leiria, Portugal, 2011.

[12] J. de Hoog, T. Alpcan, M. Brazil, D. Thomas \& I. Mareels, «Optimal Charging of Electric Vehicles Taking Distribution Network Constraints Into Account,» IEEE Transactions on Power Systems, vol. 30, nº 1, pp. 365-375, January 2015.

[13] S. Shafiee, M. Fotuhi-Firuzabad \& M. Rastegar, «Investigating the Impacts of Plug-in Hybrid Electric Vehicles on Power Distribution Systems,» IEEE Transactions on Smart Grid, 2013.

[14] A. Moawad, G. Singh, S. Hagspiel, M. Fellah \& A. Rousseau, «Impact of Real World Drive Cycles on PHEV Fuel Efficiency and Cost for Different Powertrain and Battery Characteristics,» de EVS24 International Battery, Hybrid and Fuel Cell Electric Vehicle Symposium, Stavanger, 2009.

[15] T.-K. Lee \& Z. S. Filipi, «Synthesis and Validation of Representative Real-World Driving Cycles for Plug-In Hybrid Vehicles,» IEEE Transactions on Vehicular Technology, vol. 60, $\mathrm{n}^{\circ}$ 9, pp. 4153-4163, 2011.

[16] R. Patil, B. Adornato \& Z. S. Filipi, «Design optimization of a series plug-in hybrid electric vehicle for real-world driving conditions,» de SAE World Congr. Exh, 2010, 2010.

[17] Y. Xie, A. Z. X. H. Callum, H. Militz \& C. Mai, «Silane coupling agents used for natural fiber/polymer composites: A review,» Composites: Part A, vol. 41, no 1, pp. 806-819, 2010.

[18] K. S. Chun, S. Husseinsyah \& H. Osman, «Mechanical and Thermal Properties of Coconut Shell Powder Filled Polylactic Acid Biocomposites: Effects of the Filler Content and Silane Coupling Agent,» Journal of Polymer Research, vol. 19, n 5, pp. 1-8, 2012.

[19] S. Kong, H.-C. Cho, J.-U. Lee \& S.-K. Joo, «Probabilistic Modeling of Electric Vehicle Charging Load for Probabilistic Load Flow,» de IEEE Vehicle Power and Propulsion Conference, Seoul, Korea, 2012.

[20] M. Shaaban \& E. El-Saadany, «Probabilistic Modeling ofPHEV charging load in distribution systems,» de 3rd International Conference on Electric Power and Energy Conversion Systems, Istanbul, Turkey, 2013.
[21] F. Yi \& F. Li, «An Exploration of a Probabilistic Model for Electric Vehicles Residential Demand Profile Modeling,» de IEEE Power and Energy Society General Meeting, San Diego, California, 2012.

[22] Unión Temporal Steer Davies Gleave \& Limited | Centro Nacional de Consultoría, «Informe de indicadores Encuesta de Movilidad de Bogotá 2011,» Alcaldía Mayor de Bogotá \& Secretaría de Movilidad, Bogotá D.C., 2011.

[23] Duarte Guterman \& Cia. Ltda. , «Formulación del Plan Maestro para Bogtá D.C.,» Alcaldía Mayor de Bogota - Secretaría de Transito \& Transporte, Bogotá D.C., 2006.

[24] D. Martínez, El impacto del vehículo eléctrico en la red de distribución, Barcelona, 2012.

[25] C. C. Mendoza G. \& A. M. Quintero M., Gestión en tiempo real de recarga de vehículos eléctricos en la ciudad de Bogotá, Bogotá, 2013.

[26] C. Mendoza, A. Quintero, F. Santamaria \& J. Alarcon, «Impact Analysis of Plug-in Electric Vehicles on an Electric Distribution Network,» de Transmission \& Distribution Conference and Exposition - Latin America (PES T\&D-LA) 2014, Medellín, 2014.

[27] A. C. Miller \& J. C. Berg, «Effect of silane coupling agent adsorbate structure on adhesion performance with a polymeric matrix,» Composites Part A: Applied Science and Manufacturing, vol. 34, $\mathrm{n}^{\circ}$ 4, pp. 327-332, 2003.

[28] L. Xue, G. T. Lope \& P. Satyanarayan, «Chemical Treatments of Natural Fiber for Use in Natural Fiber-Reinforced Composites: A Review,,» Journal Polymers Enviromental, vol. 15, nº 1, pp. 25-33, 2007.

[29] C. Castro, A. Palencia, I. Gutiérrez, G. Vargas \& P. Gañán, «Determination of optimal alkaline treatment conditions for fique fiber bundles as reinforcement of composites materials,» Revista Técnica Ingeniería Universidad de Zulia, vol. 30, n² 2, pp. 136-142, 2007.

[30] L. Fang, L. Chang, W.-J. Guo, Y. Chen \& Z. Wang, «Influence of silane suface modification on veneer on interfacial adhesion of wood-plastic plywood,» Applied surface sicence, vol. 288, $\mathrm{n}^{\circ}$ 1, pp. 682-689, 2014.

[31] O. Asumani, R. Reid \& R. Paskaramoorthy, « The effects of alkalisilane treatment on the tensile and flexural properties of short fibre non-woven kenaf reinforced polypropylene composites,» Composites: Part A, vol. 43, n 1, pp. 1431-1440, 2012.

[32] G. Grubbstrom \& K. Oksman, «Influence of wood flour moisture content on the degree of silane- crosslinking and its relationship to structure- property relations of wood thermoplastic composites,» Composites science and technology, vol. 69, $\mathrm{n}^{\circ}$ 7-8, pp. 1045-1050, 2009.

[33] D. Cho, H. Lee \& S. Han, «Effect of fiber surface modification on the interfacial and mechanical properties of kenaf fiber-reinforced thermoplastic and thermosetting polymer composites,» Composite Interfaces, vol. 16, $\mathrm{n}^{\circ}$ 7, pp. 11-29, 2009.

[34] M. Bengtsson, P. Gatenholm \& K. Oksman, «The effect of crosslinking on the properties of polyethylene/wood flour composites,» Composites Science and Technology Journal Impact Factor \& Information, vol. 65, n 10, pp. 1468-1479, 2005.

[35] D. Govindarajan \& G. Jayalakshmi, «XRD, FTIR and Microstructure Studies of Calcined Sugarcane Bagasse Ash,» Advances in Applied Science Research, vol. 2, n 3 , pp. 544-549, 2011. 